\title{
A Medical "Dead End" Job? The Recruitment and Career Progression of the Edwardian School Medical Officer
}

\author{
J DAVID HIRST*
}

Until the inauguration of a national system of school medical inspection in $1908^{1}$ there were only a few full-time School Medical Officers (SMOs) in England and Wales. Some doctors had previously worked for Local Education Authorities (LEAs); indeed, even before the creation of the LEAs under the 1902 Education Act, some of the larger School Boards had appointed medical officers to carry out various duties including a general supervision of schools and school children. Most were part-time appointments. In 1902, the Congress of the Sanitary Institute in Manchester attracted seven School Board medical officers from Lancashire and Yorkshire as delegates, in addition to James Kerr, Medical Officer to the London School Board. ${ }^{2}$ Only Kerr, and his successor as Medical Officer to the Bradford School Board, Dr Ralph Crowley, were employed full-time. After the formation of the LEAs, more appointments were made, but most continued to be part-time, and were often held by the local Medical Officer of Health (MOH). Only in the larger LEAs was it more usual for the appointment to be given to a doctor independent of the Public Health Service. ${ }^{3}$ The advent of the School Medical Service (SMS) thus created a substantial new demand for medical staff, particularly for subordinates to conduct the required medical inspections. ${ }^{4}$ In his Annual report for 1910 the Chief Medical Officer to the Board of Education, George Newman, could report that 995 doctors were working within the SMS in a full- or part-time capacity. ${ }^{5}$ Almost all had been appointed by the LEAs within the previous two years.

* J David Hirst, PhD, School of Sociology and Social Policy, University of Wales, Bangor.

The author would like to thank Prof. W F Bynum, Dr Bernard Harris and two anonymous referees for information, suggestions and corrections to an earlier draft of this paper.

\footnotetext{
${ }^{1}$ Under the Education (Administrative Provisions) Act of 1907, 7 Edw. 7. c. 43.
}

\footnotetext{
${ }^{2}$ Sanitary Institute, 'Congress Report', $J$. Sanit. Inst., 1902-3, 23: supplement, 119.

${ }^{3}$ See Inter-Departmental Committee on the Medical Inspection and Feeding of Children Attending Public Elementary Schools, vol. 1, Report, Cd. 2779, pp. 94-7. BPP 1906, xlvii.

${ }^{4}$ Initially, of all "entrants" and "leavers".

${ }^{5}$ Board of Education, Annual report of the Chief Medical Officer for 1910, Cd. 5925, p. 16. BPP 1911, xvii. The 1910 Annual report would contain statistics compiled at 31 March 1911.
} 
As two recent additions to the literature on the SMS have noted, ${ }^{6}$ the rapid expansion of medical inspection, though welcome in a profession then seen as overstocked, ${ }^{7}$ led to comment on the calibre of the recruits, and, subsequently, on their morale and career prospects. The MOH for Cheshire, Meredith Young, wrote:

At present medical inspection is an occupation with a "dead end" ... there is no doubt that if the best men are to be attracted and retained in the school medical service this defect will have to be remedied by the assurance of a definite progression not merely in salary but also in status and responsibility. We are at present running the risk of filling the ranks of this branch of the medical profession with juniors who will always be content to remain juniors, or with seniors who have dropped out of the fight of general practice to seek something with less strenuous demands on energy and with more regular and certain income. ${ }^{8}$

The SMOs themselves expressed dissatisfaction with the monotony of the work, the poor prospects of promotion and the low salaries compared with other public medical appointments. A letter in the Lancet complained:

There has been a feeling of discontent for some time past among the majority of those actually engaged in the work of medical inspection of school children. In the greater number of areas an undue proportion of the work of these officers consists in the routine inspection of a large number of children, a considerable proportion of whom present no feature of especial interest to a medical man. The salary offered for the work is usually inadequate; the initial salary is in most cases too low; rarely is the increased value of the services of the officer acknowledged by an adequate increase in his or her salary. ${ }^{9}$

This pattern of rapid recruitment followed by apparent disillusionment, at least among those doing the actual work of medical inspection, raises questions about the development of medical hierarchies. The medical specialisms from which the recruits were drawn, whether they continued in the SMS, or changed to other careers in medicine or elsewhere, may indicate the processes positioning the new service within a hierarchy of medical prestige. As Woodward suggests, however:

... there is a paucity of knowledge relating to the socio-demographic profile of those in the school service-how old were they when first recruited, how long did they stay with the service, and did they regard their employment as a stepping stone to further employment and promotional opportunities within school or other aspects of public salaried medical service, or within general practice? ${ }^{10}$

It is suggested in this paper that it is possible to obtain, from contemporary printed sources, details of the doctors practising within the SMS, and to examine

\footnotetext{
${ }^{6}$ Bernard Harris, The health of the schoolchild, Buckingham, Open University Press, 1995; John Woodward, 'The School Medical Officer before the School Medical Service, 1850-1908', in John Woodward and Robert Jütte (eds), Coping with sickness: historical aspects of health care in a European perspective, Sheffield, European Association for the History of Medicine and Health, 1995, pp. 121-46.

${ }^{7}$ See Anne Digby, Making a medical living: doctors and their patients in the English market for
}

medicine, 1720-1911, Cambridge University Press, 1994, esp. pp. 136ff.

${ }^{8} \mathrm{~W}$ Meredith Young, 'The future of school medical inspection', Publ. Hlth. Lond., 1911, 25 : 24.

${ }^{9}$ Lancet, 1913, ii: 1504 . See also Med. Offr., 2 August 1913, 10: 51; Harris, op. cit., note 6 above, pp. 55-7.

${ }^{10}$ Woodward, op. cit., note 6 above, p. 140 . 


\section{A Medical "Dead End" Job?}

their subsequent career paths. There are methodological and other problems in using these sources, so any analysis is subject to some margin of error.

\section{Methodology}

George Newman's Annual reports as Chief Medical Officer to the Board of Education do not list all doctors employed in the School Medical Service, giving only the name of the SMO in each LEA. A statistical tabulation of the numbers of full- and part-time staff working for the Service appears from the 1909 Annual report onwards. ${ }^{11}$ A possible alternative approach would use the annual Medical Directory to identify SMOs by searching for those doctors who reported holding appointments in the SMS, but this would require a careful search of all entries in the volume, and would be incomplete, for the Medical Directory relies on doctors reporting their current appointments, and some did not. The difficulties of using this source have been explored by Dupree and Crowther in their study of the medical profession in Scotland. ${ }^{12}$

There is, however, one source which sought to list all the staff of the SMS. In 1910 and 1911 the Public Health Services Directory and Year Book (PHSD) was published.$^{13}$ From the lack of succeeding volumes, it would seem that the publication was not a commercial success, but the 1911 issue provides a list of SMS medical staff, apparently compiled from a questionnaire to all LEAs. The PHSD lists the surnames and initials of the doctors, and in most cases their professional qualifications. Sometimes other details are included; the salary, the title of the post occupied, and whether the doctor was employed full- or part-time. The combination of surname, initials and qualifications given in the PHSD allows names to be checked against the Medical Directory. In a small number of cases the initials given in the two sources varied, but in these instances the biographical details in the Medical Directory, including the current post held, confirmed the identity of the officer. While the $P H S D$ does not itself say when its list was compiled, comparison of the curricula vitae of doctors appearing in the list with those in the Medical Directories for 1910 and 1911 suggests a date somewhere between the dates on which material for these publications was collected, that is, between September 1909 and September $1910 .^{14}$

Doctors working for the SMS fell into three broad categories, only one of which is relevant to this paper. The first group were the titular heads of the Service in each LEA. Usually, this was the local MOH, reflecting the advice given by the Board of Education that the SMO of the LEA be, or at least be directly responsible to, the

\footnotetext{
${ }^{11}$ Board of Education, Annual report of the Chief Medical Officer for 1909, Cd. 5426, pp. 175ff. BPP 1910, xxiii.

${ }^{12}$ Marguerite W Dupree and M Anne Crowther, 'A profile of the medical profession in Scotland in the early twentieth century: the Medical Directory as a Historical Source', Bull. Hist. Med., 1991, 65: 209-33. See also Marguerite Dupree, 'The medical profession in Scotland, 1911: the creation of a machine
}

\author{
readable database', in Evan Mawdsley, et al. \\ (eds), History and computing III: historians, \\ computers and data, Manchester University \\ Press, 1990, pp. 195-201. \\ ${ }^{13}$ Public Health Service Directory and Year \\ Book 1911, London, Hodgett's, 1911. \\ ${ }^{14}$ According to Dupree and Crowther, op. cit., \\ note 12 above, p. 211, the 1911 Medical Directory \\ was compiled from circulars sent out in \\ September 1910.
}


MOH. ${ }^{15}$ The Board was anxious that the SMS should be functionally integrated with the broader Public Health Service at some later date. In larger authorities, the Chief Officer might have little or no role other than to prepare the annual report, the medical inspection being performed by subordinates, but in many smaller LEAs the local $\mathrm{MOH}$ would also be asked to perform the inspections in exchange for a small increment in salary. ${ }^{16}$ These doctors had reached the peak of their medical careers, and had the role of SMO thrust upon them. As the questions addressed by this article are related to subordinate posts, they have been excluded.

Below the Chief Officers were two subordinate groups of doctors who performed most of the routine work of medical inspection and, in some LEAs, some restricted treatment also. The first group performed medical inspection part-time, combining this work with other roles in hospitals, public medicine or private practice. Parttime appointments were popular in rural areas, where geographical distance meant this was the most efficient arrangement, but local factors meant some urban areas also used part-timers. In London, where the London County Council continued to use the junior hospital staff it had employed prior to 1907, the preference was partly ideological. ${ }^{17}$ Usually, however, part-timers would be either what one enthusiast called a "compact body of chosen men", the local district MOHs, ${ }^{18}$ or local general practitioners. The British Medical Association had a policy of protecting the right of 'general practitioners to undertake part-time work as inspectors if they wished, and some LEAs were influenced in their choice of system by the local BMA branch. ${ }^{19}$ Most of these officers would undertake school medical inspection as a part of a wider range of duties, and were interested in the SMS only as an additional remunerated post, rather than as a means of career development. Again, these parttime staff have been excluded from the remit of this survey.

The Board of Education did not openly express a preference between full- and part-time inspectors, preferring not to provoke a dispute with the BMA. It did privately prefer a system of full-time inspectors, believing that part-time staff would have neither the time nor the incentive to take on additional commitments other than the basic inspection, and various methods of persuasion were used to encourage LEAs to appoint full-time inspectors. ${ }^{20}$ It is with the final category of medical staff that this study is concerned.

This group cannot always be precisely identified, so a number of criteria were developed to select those who were likely to be full-time officers in the SMS. These

\footnotetext{
${ }^{15}$ See Board of Education, Memorandum on medical inspection of children in public elementary schools, Circular 576, 1907, para 5.

${ }^{16}$ See Sch. Hyg., 1910, 1: 605ff.

${ }^{17}$ Inter-Departmental Committee on the Medical Inspection and Feeding of Children Attending Public Elementary Schools, vol. 2, Evidence and Appendices, Cd. 2784, evidence of Dr James Kerr, p. 236. BPP 1906, xlvii; See also J D Hirst, " "A failure without parallel": the School Medical Service and the London County Council, 1907-12', Med. Hist., 1981, 25: 281-300.
}

${ }^{18} \mathrm{~F}$ E Fremantle, the MOH for Hertfordshire. See Lancet, 1909, ii: 185; ibid., 1911, ii: 347-9.

${ }^{19}$ BMA, Medico-Political Committee, Minutes, 27 March 1906.

20 "Even a well carried out part-time scheme [of inspection] is necessarily inferior to a wholetime scheme". Board of Education to Yorkshire (North Riding) Education Committee, quoted in Local Govt. Chron., 1911, p. 939. See also Board of Education, Annual report of the Chief Medical Officer for 1912 , Cd. 7184 , p. 8. BPP 1914, xxv. 


\section{A Medical "Dead End" Job?}

Table 1

Identifying characteristics, full-time Assistant SMOs

\begin{tabular}{|c|c|c|}
\hline Characteristic and Source & Inclusive Factor & Exclusive Factor \\
\hline Staff numbers $(P H S D)$ & More than one & One only \\
\hline \multirow[t]{2}{*}{$\begin{array}{l}\text { Description of post } \\
(P H S D)\end{array}$} & $\begin{array}{l}\text { Assistant School Medical } \\
\text { Officer (and Assistant } \\
\text { Medical Officer of Health) } \\
\text { School Medical Inspector }\end{array}$ & $\begin{array}{l}\text { School Medical Officer and } \\
\text { Medical Officer of Health } \\
\text { Chief School Medical } \\
\text { Officer/Inspector }\end{array}$ \\
\hline & full-time & part-time \\
\hline Salary $(P H S D)$ & $£ 200-£ 400$ & $<£ 200,>£ 400$ \\
\hline $\begin{array}{l}\text { Pupils per ASMO } \\
\text { (Educational Statistics/ } \\
\text { PHSD) }\end{array}$ & $\begin{array}{l}\text { Average Attendance } \\
>10,000 \text { pupils per ASMO }\end{array}$ & $\begin{array}{l}\text { Average Attendance }<10,000 \\
\text { pupils per ASMO }\end{array}$ \\
\hline Curriculum Vitae $(M D)$ & $\begin{array}{l}\text { ASMO (\& MOH) only } \\
\text { (except Territorial RAMC or } \\
\text { Medical Referee) }\end{array}$ & $\begin{array}{l}\text { Numerous posts other than } \\
\text { ASMO (and MOH) }\end{array}$ \\
\hline
\end{tabular}

are set out in Table 1. The first requirement was that the LEA should employ more than one medical officer. In many smaller LEAs, only one officer is named, and in most of these cases he was also the local MOH. This reflects the determination of the Board of Education, as expressed through both Circular 576 and its private advice to LEAs commencing their duty of medical inspection, that the work should be carried out by the $\mathrm{MOH}$, or by someone directly responsible to him. More rarely, the responsible officer was an independent officer, in most cases appointed to his post before the SMS began on a national basis. As stated, this paper is not concerned with these chief officers. Therefore only staff working for LEAs with more than one reported appointment were considered.

The second criterion was that the title of the post should indicate subordinate status within the SMS. Holders of posts described as School Medical Officer and Medical Officer of Health were eliminated. ${ }^{21}$ Those included held the posts of Assistant School Medical Officer, School Medical Inspector, or Assistant School Medical Officer and Medical Officer of Health. The inclusion of this latter category, though necessary, presents some difficulties. Those who split their duties between the medical inspection of school children and more general public health duties might have better career prospects in the general area of public medicine than those

\footnotetext{
${ }^{21}$ Inevitably, given the variety of titles used by the LEAs, there were a small number of appointments where the description was ambiguous. In Staffordshire the MOH was also the School Medical Officer, but from the outset
}

the County employed John Priestley, an experienced surgeon who had qualified in 1882 , as Senior School Medical Inspector. Because Priestley was subordinate to the $\mathrm{MOH}$, he has been included in the group being studied. 


\section{$J$ David Hirst}

officers expected to devote their whole time to the SMS. ${ }^{22}$ It is, however, impossible to distinguish between these two groups of full-time officers on the basis of their titles alone, as the British Medical Association policy on minimum salaries for SMOs allegedly encouraged some LEAs to appoint people who were, de facto, full-time SMOs as Assistant Medical Officers of Health and School Medical Officers, as this enabled them to pay a reduced salary. ${ }^{23}$ The distinction between the groups was eventually recognized by George Newman. Beginning with his Annual report for 1913, the tabulation of the numbers of full-time and part-time staff was further broken down into the numbers of whole-time staff "giving all of their time to the SMS" and others, a recognition that some full-time officers had duties outside the SMS.

The PHSD sometimes gives details of the salaries paid, and these served as a third filter, as they also indicate whether officers were likely to be full- or part-time. The British Medical Association guidelines insisted on a minimum salary of $£ 250$ for full-time officers, but some LEAs offered salaries up to $£ 50$ lower, especially in the case of women. The medical press, following the BMA's policy, refused to accept advertisements for some posts where the minimum salary was less than $£ 250 .{ }^{24} \mathrm{~A}$ salary of $£ 200$ or more suggests full-time employment in public health, though not necessarily wholly engaged on SMS duties, a lower salary indicates a part-time post or, in the case of some of the responsible officer posts, an addition to the MOHs salary in recognition of the extra responsibilities of the SMS. In Cardiff, for example, the School Medical Officer was Edward Walford, the local MOH, who received a salary of $£ 100$ for his SMS duties, but the actual work was carried out by three fulltime assistants on salaries of between $£ 220$ and $£ 250$. Conversely, the SMO of the Municipal Borough of Carmarthen, paid only £50, was part-time, and again was the local $\mathrm{MOH}$ inspecting the children in the five schools in the borough. ${ }^{25}$ Some staff listed in the $P H S D$ were explicitly described as full-time or part-time officers, and those listed as part-time officers were excluded.

If the recommended minimum salary was $£ 250$, few LEAs paid more than $£ 350$ to a doctor wholly engaged in medical inspection. Exceptionally, Worcestershire paid salaries of $£ 400$ including expenses. In London, as the work of medical inspection at this time was carried out by part-time staff recruited from local hospitals, fulltime officers were senior staff ranking equal to the Chief Officer in smaller authorities, and their salaries of between $£ 800$ and $£ 500$ annually reflect this. For this reason, the full-time officers in London have been omitted from the sample.

A full-time officer needed a minimum number of subjects to inspect. In urban areas, with schools with a relatively high attendance situated close together and good transport links, it was estimated that a ratio of about one full-time doctor to

\footnotetext{
${ }^{22}$ Harris, op. cit., note 6 above, p. 57.

${ }^{23}$ See Society of Medical Officers of Health archives, Committee Minute Book, General Purposes, Legal and Parliamentary Committee Minutes, 17 June 1909, CMAC/SA/SMO/D.1/3, Contemporary Medical Archives Centre, Wellcome Library; Med. Offr., 7 August 1909, 2: 173.
}

\footnotetext{
${ }^{24} \mathrm{Br}$. med. J., 1908, i: supplement, 243; Lancet, 1908, ii: 1042.

${ }^{25}$ Board of Education, Annual report of the Chief Medical Officer for 1913, Cd. 7730, p. $289 \mathrm{ff}$. BPP 1914-16, xviii.
} 
Table 2

Average school attendance for each full-time School Medical Officer

\begin{tabular}{lc}
\hline Average Attendance per SMO & Number of LEAs \\
\hline $10,000-14,999$ & 23 \\
$15,000-19,999$ & 21 \\
$20,000-24,999$ & 16 \\
$25,000-29,999$ & 6 \\
$30,000-34,999$ & 5 \\
$35,000-39,999$ & 3 \\
$40,000+$ & 1 \\
\hline
\end{tabular}

every 25,000 to 32,000 children in average attendance was acceptable. ${ }^{26}$ This applied where only two inspections were made of children, as they entered and before they left the school. In more rural areas the extra travelling time, the increase in the number of schools and the smaller number of children to be inspected at each, together with the greater likelihood that equipment would need to be transported and set up before the inspection, ${ }^{27}$ reduced the number of children required to justify a full-time officer, as did attempts to implement three inspections during school life. A division of duties between the SMS and general public health work further reduced the number of children per doctor, but even given these considerations, a minimum number of children was required to justify a full-time medical officer. With fewer than 10,000 children on the roll per Assistant SMO, it became more likely that the officer was spending less than 50 per cent of his or her time on the SMS. Using the Education Statistics for 1910-11, the ratio of pupils in average attendance per Assistant SMO was calculated. Doctors working for authorities with fewer than 10,000 in average attendance for each doctor listed have been excluded as likely to be part-time staff, or spending only a minor part of their time on the SMS. ${ }^{28}$ The ratios among the authorities employing those remaining in the sample are given in Table 2.

Of the four.LEAs with more than 35,000 pupils per full-time SMO, two (Derbyshire and Kingston-upon-Hull) also used part-time officers, which reduced the overall ratio, and one (Nottingham) had a staff vacancy unfilled at the time of collation of the PHSD returns. In the fourth LEA, Salford, the high ratio indicates that the LEA had provided an inadequate staff of inspectors, and it had been unable to complete the inspections required by the Board in 1911. ${ }^{29}$

\footnotetext{
${ }^{26}$ See Greater London Record Office, LCC File PH/SHS/1/14, Medical Inspection: General Enquiries File.

${ }^{27}$ Thus the description of portable equipment used in one rural area, including a weighing machine suitable for carriage on the back of a motor cycle, in K Fraser, 'Problems of school medical inspection in a rural area', Sch. Hyg., 1915, 6: 32-42, esp. pp. 34-5.

${ }^{28}$ Board of Education, Statistics of public education in England and Wales, Part 1 ,
}

Education statistics, 1910-11, Cd. 6338, Table 17 (England), pp. 38-59; (Wales), pp. 344-7. BPP 1912-13, lxiv.

${ }^{29}$ Salford managed to inspect only 4709 of the 9000 children required to be inspected in 1910. In 1911 the Board of Education threatened to withhold the grant unless additional officers were appointed to carry out the medical inspections. Salford County Borough Council, Annual report of the School Medical Officer for 1910, p. 87; PRO Ed 125/11, Precedent Cover: Salford. 
Full Time School Medical Officers: Date of First Qualification

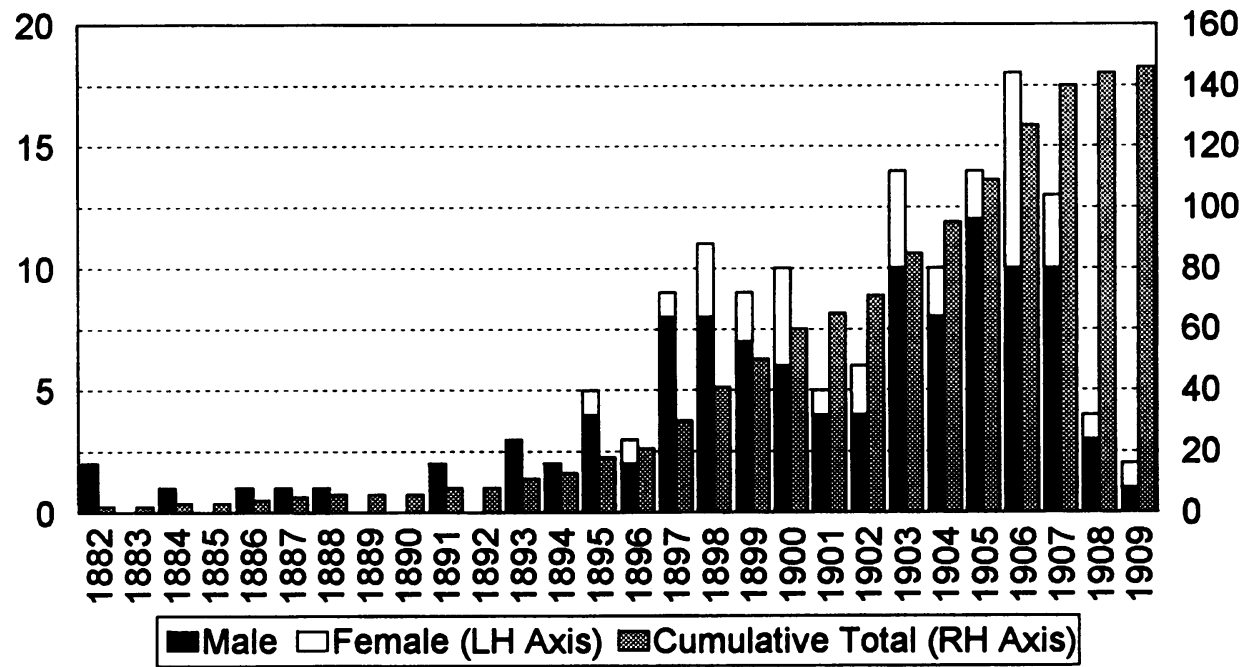

Figure 1: Recruitment, experience and background.

A comparison of the information in the $P H S D$ and the Medical Directory for 1910 and 1911 confirmed the details of name, career and qualifications in the PHSD, and the post occupied by the doctor. Apart from those holding commissions in the Territorial Force, doctors who listed other posts in the Medical Directory in addition to that of SMO, for example, as police surgeon, were also excluded at this stage as not being full-time officers. Dr Robert Douglas was found to have been recorded twice, having moved from the West Riding of Yorkshire to Norfolk during compilation of the PHSD, as his entry in the Medical Directory confirmed. His earlier record was deleted. This gave a sample of 146 doctors, working for 76 LEAs; 33 county councils, 36 county boroughs, 1 municipal borough and 6 urban districts. As might be expected, this is skewed towards the larger authorities and the county councils and county boroughs; of the 321 LEAs operating in England and Wales in 1911, 62 were county councils, 76 county boroughs, 133 municipal boroughs and 50 urban districts.

The graph shows some basic details of the length of time the sample had been working as doctors. The $\mathrm{X}$ axis shows the year individuals first appeared in the Medical Register, differentiating men and women. ${ }^{30}$ The left hand $\mathrm{Y}$ axis shows the number qualifying in each year, the right hand $\mathrm{Y}$ axis the cumulative percentage qualified. As can be seen, this was primarily a young group. Half were within ten years of their first medical qualification. Eighty per cent had qualified after 1897.

There are difficulties, as the work of Dupree and Crowther has shown, in using information taken from the Medical Directory to determine previous career histories

\footnotetext{
${ }^{30}$ Details of the date of registration were taken from the Medical Register 1911.
} 
Table 3

Previous post and length of times since registration

\begin{tabular}{lrc}
\hline Previous Post & Numbers & $\begin{array}{c}\text { Average Length of } \\
\text { Career (years) }\end{array}$ \\
\hline Hospital & & \\
Large Voluntary & 20 & 7.65 \\
Small Voluntary (Cottage Hospital, etc.) & 4 & 17.25 \\
Poor Law Hospital & 12 & 10.10 \\
Lunatic Asylum & 6 & 11.67 \\
Dispensaries & 7 & 9.00 \\
Infectious Disease/Fever/Isolation & 14 & 8.50 \\
Maternity/Women's & 4 & 9.75 \\
Children's & 10 & 6.20 \\
Eye & 5 & 10.80 \\
Tuberculosis, Chest, etc. Sanatoria & 5 & 12.20 \\
Other (1 × Ear; 1 X Oncology) & 2 & 12.50 \\
Public Service & & \\
Public Health & & 11.00 \\
School Health (previous appointment) & 15 & 7.86 \\
Inspector of Midwives & 7 & 11.00 \\
Colonial Medical Service & 1 & 12.00 \\
Other & 1 & \\
Junior teaching/demonstrating post & & 9.00 \\
Army Medical Corps & & 7.00 \\
Court Medical Assessor & 6 & 5.00 \\
Shipping Line & 4 & 7.97 \\
Medical Missionary & 1 & 21.75 \\
Other & 1 & 17.00 \\
Medical Officer (private school) & 2 & \\
& 1 & \\
No Information supplied & 1 & \\
\hline & & \\
\hline
\end{tabular}

The type of hospital was specified from information in Burdett's hospitals and charities 1911, London, 1911.

and these are, if anything, magnified when using the data for a longitudinal study. Some of the group subsequently entered information in volumes of the Medical who's who, ${ }^{31}$ providing a dated chronology which in some cases differed significantly from that contained in the Medical Directory. Nevertheless, an indication of the post held immediately before appointment to their current SMS post, and the average length of career, is given in Table 3 . The data suggests full-time appointees can be placed into three categories. The first sub-group were a small number of older

${ }^{31}$ See Medical who's who 1912, 1917 etc. London, various dates. 
doctors who were extending their medical careers after completing their first chosen specialism. This group had received their first medical qualification before 1893 . Among them were the members of the Royal Army Medical Corps, seeking new employment after ending their army careers, the Medical Missionaries and the colonial medical officer returning from abroad, and the majority of the cottage hospital surgeons. General practitioners are not formally identified in the 1911 Medical Directory ${ }^{32}$ but from the ages and careers of those listed, the four cottage hospital surgeons are the only likely candidates, it would thus seem that, contrary to Meredith Young's comments, few, if any, full-time SMOs were refugees from the stress of general practice. A second group may be designated as career commencers, obtaining their first qualification in 1904 or afterwards. This group obtained appointments after service as House Physician or Surgeon, and made up the bulk of those coming from the large voluntary hospitals and specialized women's and children's hospitals, together with some of the younger doctors from fever and tuberculosis hospitals. All the women in this group came from specialized hospitals, rather than from the general voluntary hospitals. As Mary Ann Elston's thesis indicates, women had difficulty obtaining house posts in voluntary hospitals at this time, except for those run by women, or specializing in the treatment of women and children. ${ }^{33}$ Finally, and most interestingly in assessing the place of the SMS in the medical hierarchy, there are the career changers, doctors with some years of service coming from other branches of the profession to become SMOs. This group had obtained their first qualification between 1893 and 1903.

In some cases, the transfer was from hospital appointments in specialisms seen as relevant to school health, ophthalmology, paediatrics, and infectious diseases. The public health officers in the group are an indication of the way in which school health became added to the portfolio of duties which some public health specialists were expected to deal with during their work. In other cases, such as the entrants from Poor Law hospitals and asylums, the suggestion is that the SMS might have seemed a more desirable place in the developing medical hierarchy, either through a more professionally interesting field of practice, or better salaries. The recruits from the Metropolitan Asylums Board might, depending on whether they were senior assistants or more junior, have received a salary broadly comparable with that of a SMO, or one $£ 50$ to $£ 100$ lower. ${ }^{34}$

Given the number of routes by which medical qualifications could be obtained, providing details in tabular form can be complex, and a number of different

\footnotetext{
${ }^{32}$ See Anne Crowther and Marguerite Dupree, 'The invisible general practitioner: the careers of Scottish medical students in the late nineteenth century', Bull. Hist. Med., 1996, 70: 387-413.

${ }^{33}$ Mary Ann C Elston, 'Women doctors in the British Health services; a sociological study of their careers and opportunities', $\mathrm{PhD}$ thesis, University of Leeds, 1986, pp. 224-5.

${ }^{34}$ Gwendoline M Ayers, England's first state hospitals and the Metropolitan Asylums Board,
}

1867-1930, London, Wellcome Institute for the History of Medicine, 1971, Appendix 4, Table J, p 332. Bernard Harris has suggested that it would be interesting to compare these doctors with those entering the SMS ten years later, when complaints about the monotony and lack of career prospects were more common. Difficulties in acquiring the data must, for the moment, leave this avenue unexplored. See Harris, op. cit., note 6 above, pp. 102-4. 


\section{A Medical "Dead End" Job?}

Table 4

Medical qualifications obtained

\begin{tabular}{|c|c|c|c|c|c|c|c|}
\hline Qualification & $<1892$ & 1893-1903 & $>1903$ & Total & $\begin{array}{l}\text { Fellow- } \\
\text { ship }\end{array}$ & MD & DPH \\
\hline \multicolumn{8}{|l|}{ Men } \\
\hline MRCS, LRCP etc. & $\because$ & $\therefore$ & & & & & \\
\hline (English) & 3 & 10 & 11 & 24 & 1 & 6 & 16 \\
\hline $\mathrm{MB} \mathrm{ChB}$, etc. & & & & & & & \\
\hline $\begin{array}{l}\text { (English) } \\
\text { MB + MRCS etc. }\end{array}$ & - & 11 & 12 & 23 & - & 11 & 21 \\
\hline (English) & 1 & 14 & 5 & 20 & 2 & 8 & 15 \\
\hline Conjoint (Scottish) & 2 & 2 & - & 4 & 1 & 1 & 3 \\
\hline \multicolumn{8}{|l|}{ MB ChB etc. } \\
\hline (Scottish) & 2 & 18 & 10 & 30 & - & 18 & 27 \\
\hline $\begin{array}{l}\text { Conjoint + MB etc. } \\
\text { (Scottish) }\end{array}$ & - & - & 1 & 1 & - & - & - \\
\hline LRCPI etc. (Irish) & - & - & 1 & 1 & - & - & -1 \\
\hline BAO (Irish) & - & 3 & 4 & 7 & - & 5 & 6 \\
\hline \multicolumn{8}{|l|}{ Women } \\
\hline \multicolumn{8}{|l|}{ MB ChB, etc. } \\
\hline Conjoint (Scottish) & - & 2 & 2 & 4 & - & - & 1 \\
\hline \multicolumn{8}{|l|}{ MB ChB etc. } \\
\hline (Scottish) & - & 9 & 4 & 13 & - & 3 & 10 \\
\hline LRCPI etc. (Irish) & - & 1 & - & 1 & - & - & - \\
\hline BAO (Irish) & - & 1 & - & 1 & - & 1 & 1 \\
\hline Total & & & & & 4 & 59 & 112 \\
\hline
\end{tabular}

approaches have been tried. ${ }^{35}$ Table 4 shows details of both the initial qualifications and highest medical qualification achieved by those in the sample. It does not attempt to explore other possible variables, such as distinguishing between graduates of English and Welsh provincial schools, and the London system.

For initial qualifications, the table indicates the country of origin, and whether the qualification was obtained by a university degree or College qualification. In addition to the basic qualification, most members of the sample eventually obtained a specialized postgraduate qualification in public health. By 1888 the Local Government Act had effectively turned the Diploma in Public Health into an exclusive licence to practise as an $\mathrm{MOH} .{ }^{36}$ In 1907, however, the Board of Education felt

\footnotetext{
${ }^{35}$ See, for example, Dorothy E Watkins,

'The English revolution in social medicine, 1889-1911', unpublished PhD thesis, University of London, 1984, p. 50; Dupree and Crowther, op. cit., note 12 above, p. 220. For a
}

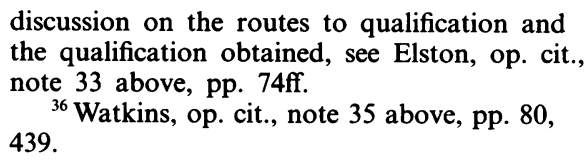
the qualification obtained, see Elston, op. cit., note 33 above, pp. 74ff. 439.

${ }^{36}$ Watkins, op. cit., note 35 above, pp. 80 , 


\section{$J$ David Hirst}

unable to require possession of a DPH by SMOs, suggesting only that "preference should be given to medical men and women who ... have had adequate training in state medicine or hold a Diploma in Public Health". ${ }^{37}$ In practice, 99 had obtained a DPH by or during 1911. Of the 13 who obtained their qualification subsequently, 10 did so during 1912 and 1913; Harry Burpitt, the last of the sample to obtain this qualification, did so in 1921.

Dorothy Watkins has explored the changing patterns of medical qualifications of those appointed to posts as $\mathrm{MOH}$, and the gradual replacement of Fellows of the Royal Colleges by those holding postgraduate qualifications in public health. Though the DPH was intended as a qualification equivalent to MRCP, FRCS or MD, ${ }^{38}$ many in the sample also obtained other higher qualifications. Only 4 were, or became, Fellows of either the English or Scottish Colleges, but 59, of whom 10 were women, obtained an MD. Fifty-one of these, including 8 women, held both the MD and the DPH. Twenty-seven had obtained the MD before the DPH, 24 obtained their MD after, or in the same year as, their DPH, an indication that an additional qualification was still seen as desirable. A DPH would, however, clearly be a prerequisite for eventual progression to a senior post in public medicine. Of the 34 who failed to obtain a DPH therefore, some remained as junior staff throughout their careers, some were among those who transferred to other posts, or abroad.

\section{Gender, Careers and Commitment}

There have been a number of recent studies of the "second generation" of women medical graduates and their careers. ${ }^{39}$ As Elston emphasizes, a combination of institutional barriers and a view that the care of children and women was particularly suitable for women doctors led to a concentration, both in basic placements and subsequent careers, in certain posts. Thus women doctors were well represented within the SMS. Of the 146 full-time subordinate officers identified, 36 were women. As the 1911 Census records only 477 women working as Physicians, Surgeons and Registered Practitioners in England and Wales, against $22,992 \mathrm{men},{ }^{40}$ this means that the SMS was one of the prime avenues for the employment of women doctors, with more than 7 per cent of all active women doctors among its full-time employees. A further 39 women can be identified from the $P H S D$ as sole officers or part-time

\footnotetext{
${ }^{37}$ Board of Education, Memorandum on medical inspection of children in public elementary schools, Circular 576, 1907, para 7.

${ }^{38}$ Watkins, op. cit., note 35 above, p. 120.

${ }^{39}$ Wendy Alexander, First ladies of medicine: the origins, education and destination of early women medical graduates of Glasgow University, University of Glasgow, Wellcome Unit for the History of Medicine, 1987; Wendy Alexander, 'Early Glasgow women medical graduates', in Eleanor Gordon and Esther Breitenbach (eds), The world is ill-divided: women's work in Scotland in the nineteenth and early twentieth centuries, Edinburgh University Press, 1990, pp. 70-94;
}

Carol Dyhouse, 'Driving ambitions: women in pursuit of a medical education, 1890-1939', Women's History Review, 1998, 7: 321-41; Elston, op. cit., note 33 above; Digby, op. cit., note 7 above, pp. 290-5.

${ }^{40}$ Census of England and Wales, 1911, Volume 10, Part 1, Occupations and industries, Cd. 7018. Table 1, p. 2. BPP 1913, lxxviii, These figures exclude retired practitioners. Elston points out that the numbers of women on the Medical Register at this time were higher, but this would include some not actively practising, or abroad. Elston, op. cit., note 33 above, p. 57 . 


\section{A Medical "Dead End" Job?}

staff, meaning that the SMS accounted for at least part of the work of 15 per cent of the women then active in medical practice. This may be a reflection of the difficulties faced by female doctors in entering other areas of the profession, or a perception that some posts were more suited to them. ${ }^{41}$ Some LEAs deliberately appointed women so they could inspect girls, as concern about "modesty" meant older girls were among the groups most likely to refuse inspection, either directly or through absence on the day of the inspection. ${ }^{42}$

One of the earlier reports of the Chief Medical Officer to the Board of Education indicated that six women had been appointed to the post of Principal (Chief) School Medical Officer for their areas, suggesting that, at the outset, the SMS enabled women medical officers to achieve a status denied them in other fields of public medicine. ${ }^{43}$ Such an assumption might, however, be misleading. Four of the six female Chief Officers were receiving a salary less than the BMA recommended minimum for full-time school health work. ${ }^{44}$ The appointment of a woman thus reflected a desire to keep down the cost of the new service. In Scotland, where the equivalent legislation gave responsibility for medical inspection to the School Boards, a further factor is evident; the desire not to disturb existing differentials between men and women teachers. Here, male officers were offered $£ 250$, females between $£ 150$ and $£ 200$. A letter in the Lancet explained "that if the female medical inspectors are remunerated at the same scale as the males the female teachers will demand like treatment". ${ }^{45}$ One effect of the Board's policy of making the Medical Officer of Health the responsible officer was to destroy the professional autonomy of any female Chief School Medical Officers, for Medical Officers of Health were, and remained, posts reserved exclusively for men.

The effects of these barriers can be identified by following the group through their medical careers. Data from the 1914 Medical Directory indicates how the process of movement and differentiation had already begun. While the information in the $P H S D$ was apparently supplied by the LEAs, it is the doctors themselves who give details of their posts and job titles in the Medical Directory. As Table 5 indicates, in 1914 most of the group were still in public medicine, but the distribution of roles had widened, and gender differences become apparent.

Of those whose posts were known, all but 6 remained in public health work in Britain. Seventeen, all male, were now occupying Chief Officer positions in public health. A further 17, only one of whom was a woman, had by now become Tuberculosis Officers, together with one who had taken up a post at a Tuberculosis

\footnotetext{
${ }^{41}$ See Digby, op. cit., note 7 above, pp. $290 \mathrm{ff}$.

${ }^{42}$ At Hull in 1912, there were thirty seven parents who actively objected to medical inspection, but there was also "a form of passive resistance to inspection ... that they simply keep their children at home on the day of inspection". This had happened with sixteen male and sixty six female school leavers. Hull County Borough Council, Annual report of the School Medical Officer for 1912, p. 131.

${ }^{43}$ Annual report of the Chief Medical Officer to the Board of Education for 1909, Cd. 5426, p. 194.
}

BPP 1910, xxiii; Digby, op. cit., note 7 above, pp. 294-5.

${ }^{44}$ PRO Ed 125/8, Precedent Cover: Colchester, 9 October 1909. The four women were the Chief Officers at Colchester, Barrow, Aston Manor and Bromley. There were six male officers in the same position. Five of the thirteen full-time assistants receiving less than $£ 250$ per annum were also women.

${ }^{45}$ Education (Scotland) Act, 1908, 8 Edw. 7. c. 63. Lancet, 1909, ii: 46. 


\section{J David Hirst}

Table 5

Description of main employment in 1914 Medical Directory by sex

\begin{tabular}{lcc}
\hline Type of Post & Male & Female \\
\hline Hospital Appointment, United Kingdom & 2 & - \\
Chief Medical Officer of Health & 17 & - \\
Assistant Medical Officer of Health, etc. & 25 & 3 \\
Medical Officer, Education Committee, etc. & 40 & 28 \\
Tuberculosis Officer & 16 & 1 \\
Medical Officer, Poor Law School & - & 1 \\
Medical Officer, Private School & 1 & - \\
Overseas & 2 & - \\
Unknown & 7 & 3 \\
\hline
\end{tabular}

Hospital. The leakage to TB officer posts is attributable not only to the 1911 legislation creating these positions under the Health Insurance scheme, ${ }^{46}$ but also to the salary differential between the appointments. Compared with the $£ 250-£ 350$ offered to SMOs, a Tuberculosis Officer could obtain $£ 500$ per annum. To some degree, doctors might also have had a greater degree of clinical satisfaction from a tuberculosis appointment. The sex distribution meant women were effectively excluded from these more lucrative posts. Equally significant is the way in which women were concentrated among posts they described as School Medical Inspector, Medical Officer, Education Committee, etc. A distinction can be made between those who described themselves as Medical Officer to the Education Committee, or similar title, which implied an exclusive devotion to SMS work, and those now calling themselves Assistant Medical Officer of Health or similar title, which might indicate a wider range of work experience. ${ }^{47}$ In this sense, the women were being ghettoised in educational medicine, and were being denied a wider experience which might offer them more chance of career progression. Even where illness or chance gave women the opportunity to lead temporarily, they would find a man appointed to the permanent post. Sophia Seekings (Friel), one of the subjects of this study, was appointed Acting $\mathrm{MOH}$ in 1912 due to illness of the incumbent, but in 1913 a man was appointed over her head. ${ }^{48}$

The impact of the First World War adds a further dimension to the uncertainties

\footnotetext{
${ }^{46}$ See Lynda Bryder, Below the magic mountain: a social history of tuberculosis in twentieth century Britain, Oxford, Clarendon Press, 1988, pp. 36ff. Although more highly paid than posts in the SMS, Bryder notes on pp. 72-3 that appointments as Tuberculosis Officers were also described as "professional suicide" and as a "dead end job". See also F B Smith, The retreat of tuberculosis 1850-1950, London, Croom Helm, 1988.

${ }^{47}$ The BMA had anticipated the possible problems in 1909, when its Medico-Political
}

Committee had recommended that where SMOs were appointed as AMOHs their duties "should be such as would enable the holder to base a claim for appointment as medical officer of health on the experience gained in this appointment", a statement which implicitly excluded those working wholly in the School Medical Service from this category. Med. Offr., 22 May 1909, 1: 937.

${ }^{48}$ Elston, op. cit., note 33 above, p. 255. 


\section{A Medical "Dead End" Job?}

Table 6

Careers of women who were full-time SMOs in 1911

\begin{tabular}{lrrrrrrr}
\hline & 1914 & 1917 & 1920 & 1923 & 1926 & 1929 & 1932 \\
\hline AMOH, AMOH + & & & & & & & \\
ASMO & 3 & 4 & 5 & 5 & 6 & 6 & 6 \\
MO (Education) & 28 & 17 & 14 & 13 & 11 & 10 & 10 \\
AMOH + TB, TB & 1 & 4 & 2 & 1 & 1 & 2 & 1 \\
MOH (Chief Officer) & 0 & 0 & 0 & 0 & 0 & 0 & 0 \\
Other & 2 & 3 & 4 & 5 & 5 & 4 & 5 \\
Unknown; Retired & 2 & 8 & 11 & 12 & 13 & 14 & 14 \\
\hline
\end{tabular}

surrounding the accuracy of the Medical Directory, with relatively few of this group reporting service posts in the 1917 and 1920 Directories. It is known that SMOs were absorbed into the armed forces in increasing numbers after 1916, but it is difficult to compare the percentages with those for other groups. By March 1917, over 30 per cent of the pre-war strength of doctors in the SMS had joined the armed forces, and in April the War Office called up more of those remaining. ${ }^{49}$ After the War, throughout the 1920s, some members of the group continued to list their employment as Service or Friends Ambulance units.

While inaccuracies may be present, the subsequent careers of these doctors continue to show the differences between the genders. The medical careers of the women are shown in Table 6 . Women who were still known to be actively working tended to remain in SMS work, especially as Medical Officers (Education). Of the twenty-two women still known to be in practice in 1932 ten remained as SMOs, or as Medical Officers to the Education Committee. Only five were Assistant MOHs, though there is some evidence that the more generic title began to be used during the $1920 \mathrm{~s}$, even if the duties of the post itself did not change. A maximum of four women doctors in any one year had been described as Tuberculosis Officers, and by 1932 only one remained. Apart from a hospital ophthalmologist, an officer at a private mental asylum and a couple of doctors working overseas in missionary organizations or the armed forces, only one woman doctor working in maternity and child welfare (another largely female preserve) and one working for the Ministry of Health relieved the monotony. The overseas posts suggest that for some women doctors, the opportunity to progress in the profession was enhanced by foreign service. Frances Harper was reported to be the Medical Officer of the English Mission to Czechoslovakia, while Myra Mackenzie had lately been the Assistant Medical Officer of the Scott Women's Hospital, Macedonia and Serbia. ${ }^{50}$ None had achieved Chief Medical Officer of Health status, though some were now bearers of titles indicating some degree of seniority within the ranks, such as "Senior SMI", or similar. Most of the women whose marital status can be determined from the various sources were

\footnotetext{
${ }^{49}$ Board of Education, Annual report of the School Medical Officer for 1916, Cd. 8746, p. 1. BPP 1917-18, xi.
}

${ }^{50}$ Entries in Medical Directory, 1926. 


\section{J David Hirst}

Table 7

Careers of men who were full-time SMOs in 1911

\begin{tabular}{lrrrrrrc}
\hline & 1914 & 1917 & 1920 & 1923 & 1926 & 1929 & 1932 \\
\hline AMOH, & & & & & & & \\
AMOH + ASMO & 25 & 17 & 16 & 17 & 15 & 11 & 11 \\
MO (Education) & 40 & 28 & 19 & 16 & 14 & 14 & 12 \\
AMOH + TB, TB & 16 & 21 & 16 & 11 & 11 & 10 & 7 \\
MOH (Chief Officer) & 17 & 23 & 24 & 32 & 30 & 29 & 25 \\
Other & 5 & 10 & 17 & 17 & 18 & 22 & 25 \\
Unknown; Retired & 7 & 11 & 18 & 17 & 22 & 24 & 30 \\
\hline
\end{tabular}

single, as might be expected, but at least four of the full-time women SMOs were, or had been, married, indicating that this was not a total bar on continuing employment. ${ }^{51}$ Married women teachers, and married women staff of the Central Department, would not have been so fortunate. ${ }^{52}$ Perhaps not unexpectedly, as no attempt has been made to trace marriages and consequent changes of surname, a higher proportion of the females are in the unknown or retired employment category.

The contrast with the medical careers of the men is striking. Their subsequent careers are shown in Table 7. The numbers becoming Chief Officers continued to grow after 1914. By 1923, 32 male doctors claimed that title. In contrast to the women, only a minority of the men recorded themselves exclusively as School Medical Inspector or similar by 1914. Again, however, the future career lay almost exclusively in the field of public health or public medicine in general. New fields produced new careers, in the Central Departments of the Ministry of Pensions and National Insurance, for example, and in the Ministry of Health. One officer became an inspector with the Home Office, under the Cruelty to Animals Acts. Few returned to hospital work, though two former Tuberculosis Officers obtained appointments in chest and tuberculosis hospitals, one became the proprietor of a private mental hospital, and four others had, by 1932, returned to hospital work in one form or another.

The different experiences of the two sexes can be further illustrated by examining the pattern of careers in 1926, fifteen years after the first record of their appointments in the SMS. The pattern is shown in Table 8. For some, a second career beckoned after retirement from public health work. One doctor became a coroner, two others became medical referees for insurance companies, and one became a medical officer

\footnotetext{
${ }^{51}$ Mrs Alice Burn, Mrs Ada McLaren, Mrs Lucy Pinniger, and Mrs Mary Frances Williams, who had previously worked with the Colonial Service in Gambia, and with the Ashanti Field Force. It is not known if they had been widowed. Some of the women medical officers who become untraceable in the Medical Directory may have changed their name on marriage.
} 
Table 8

Description of main employment in 1926 Medical Directory by sex

\begin{tabular}{lrr}
\hline Type of Post & Male & Female \\
\hline Hospital Appointment, United Kingdom & 6 & 1 \\
Chief Medical Officer of Health & 30 & - \\
Assistant Medical Officer of Health, etc. & 15 & 6 \\
Medical Officer, Education Committee, etc. & 14 & 11 \\
Tuberculosis Officer & 11 & 1 \\
Medical Officer, Maternity and Child Welfare & - & 1 \\
Medical Officer, Pensions \& National Insurance & 3 & - \\
Medical Officer, Ministry of Health & 1 & - \\
Medical Officer, Cruelty to Animals Acts & 1 & - \\
Military and analogous appointments & 2 & - \\
Medical Officer, Private School & 1 & - \\
Medical Referee, Insurance Company & 2 & 2 \\
Lecturer, Medical Charity* & - & 13 \\
Overseas & 2 & - \\
Unknown & 22 & - \\
\hline
\end{tabular}

* National Society for Combatting Venereal Disease

for the Post Office. Reginald Lawrence, after a career as Assistant SMO in Cheshire, and Assistant $\mathrm{MOH}$ in the West Riding of Yorkshire, became a general practitioner on retirement. ${ }^{53}$

From the evidence in this study, some of the opinions about the early recruits to the SMS can be qualified. Relatively few of them were "seniors who have dropped out of the fight of General Practice", though some were extending their medical careers after work in other types of medical practice. Most were "juniors", young doctors in the first years after their qualification. Despite Meredith Young's concern about the calibre of those who might be attracted to the SMS, most of the men in the sample were eventually promoted or obtained other medical employment. Most remained in public medicine, though for those who had more opportunities the SMS seems to have been placed in a subordinate position in the hierarchy of career preferences to work as a Tuberculosis Officer or in general public health medicine. The lack of promotion among women postholders was due less to their being "content to remain juniors", than to a combination of gender and a public medical service structured to favour those with generic experience.

From the pattern of entry and loss, it can be suggested that the SMS quickly found its place in the hierarchy of medical preferences for publicly funded appointments. It ranked more highly than the Poor Law medical service, or posts in lunacy and mental deficiency institutions, suggesting that work with children was seen as preferable to work with stigmatized groups. Tuberculosis or public health medicine in general were, however, seen as preferable to exclusive work in the SMS. For this

${ }^{53}$ Obituary, Br. med. J., 1959, i: 723. 


\section{$J$ David Hirst}

a combination of reasons may be offered; higher salaries, greater clinical satisfaction, and above all better prospects for promotion to the status of Chief Departmental Officer are all likely factors. A generic post in public health, rather than any specialism in school health or tuberculosis, was rightly seen as the best route to senior positions in public medicine. The losses to other forms of public medicine might have been higher had it not been for the significant proportion of women doctors in the SMS. Often provided with job descriptions which effectively barred promotion in the wider field of public health, they were most likely to continue working as medical inspectors of school children.

Although losses from the SMS give some credence to complaints about monotony, boredom and lack of promotion prospects within the service itself, these should perhaps be put into perspective. The salary, though a source of complaint, was a guaranteed income, however inadequate the recipients may have considered it to be, and that income was both more certain and possibly more generous than that received by many doctors in the immediate pre-war period. According to Guy Routh, the median income for male doctors in 1913/14 was $£ 390$, and only $£ 195$ at the lowest quartile. ${ }^{54}$ Moreover, unlike general practice, there was no need to pay a premium or seek a partnership in order to practice. For many doctors in the SMS, including women, whose prospects for advancement or a change of career were limited, the salary may have been a considerable compensation for years inspecting predominantly healthy children.

${ }^{54}$ See Guy Routh, Occupation and pay in
Great Britain 1906-1979, 2nd ed., London,
Macmillan, 1980, p. 60. See also Digby, op. cit., note 7 above. 